\title{
ANALISIS HUBUNGAN ANTARA INFLASI DAN PERTUMBUHAN EKONOMI: KASUS INDONESIA
}

\author{
Ismail Fahmi Lubis \\ Program Pascasarjana Universitas Negeri Medan \\ Sumatera Utara, Indonesia \\ Telp. 082164635402; Email: ismailfahmilbs007@gmail.com
}

\begin{abstract}
The Phenomena and trends of level of inflation which seem to be high as caused by factors or government policies whilst the level of economic growth averagely shows high and sustainable growth drawing the unusual macroeconomic condition in Indonesia. This research is conducted to find Correlation and Short-run as well as Long-run relationship between inflation and economic in Indonesia during 19682012. Besides, it is to find Granger-Causality between the Consumer Price Index (CPI) and Gross Domestic Product (GDP). It first tests its Unit-Root by Augmented Dickey Fuller and Dickey Fuller test, then it tests its Cointegration by Johansen Cointegration test and its causal relationship by Granger-Causality test as well as it makes mechanism of Error Correction Model (ECM). It is found both inflation and economic growth have no Unit-Root. It is found both inflation and economic growth have Correlation. It is found significantly long-run relationship through the probability value of its residual and short-run relationship through the probability value of inflation and economic growth in its differentiation. It is then found significantly one-way Granger-causality GDP causes CPI but not found one-way Granger-causality CPI causes GDP.
\end{abstract}

Keywords: Inflation, Economic Growth

\section{PENDAHULUAN}

nflasi yang terjadi di Indonesia di sepanjang tahun 1968 sampai 2012 mengalami inflasi yang tinggi dan berlangsung secara terus menerus dan telah berakar di sepanjang sejarah ekonomi Indonesia sementara pertumbuhan ekonomi mengalami pertumbuhan ekonomi yang cukup tinggi dan secara terus menerus/berkesinambungan (high sustainable

QE Journal | Vol.03 - No.01 - 41 
economic growth). Perubahan politik di tahun 1966 dan reformasi ekonomi dan stabilisasi keamanan membuat tingkat inflasi turun dalam waktu yang singkat. Sejak akhir 1960an sampai akhir 1990an dilanjutkan sampai tahun 2012 Indonesia mengalami inflasi yang sedang dalam rata-rata sekitar 10-15 persen setiap tahun kecuali selama terjadi empat gonjangan eksternal. Inflasi tahun 1968 mencapai 126,32 persen yang mana masih dipengaruhi kuat oleh hiperinflasi masa orde lama.

Ahluwaliyah (2013) mengatakan inflasi yang terjadi seharusnya dapat dikendalikan/dikontrol sehingga tingkat inflasi tersebut dapat memberikan dampak positif terhadap pertumbuhan ekonomi. Mallik dan Chowdhurry (2001:123) mengatakan pertumbuhan ekonomi yang terlalu cepat dapat mengakibatkan inflasi atau keadaan ini disebut ekonomi dalam keadaan terlalu panas (overheating economy).

Investopedia (2013:1) inflasi merupakan tingkat dari harga-harga umum barang dan jasa naik, dan mengakibatkan kekuatan membeli (purchasing power) turun. Sentral Bank mencoba menghentikan inflasi yang akut dan juga deflasi yang parah dalam usahanya untuk menjaga pergerakan harga yang berlebihan sekali menuju tingkat minimumnya. Friedman dan Baily (1995:18) inflasi adalah terjadinya kenaikan tingkat harga secara keseluruhan. BI mendefinisikan inflasi adalah meningkatnya harga-harga secara umum dan terus-menerus dan kenaikan harga dari satu atau dua barang saja tidak dapat disebut inflasi kecuali bila kenaikan itu meluas atau mengakibatkan kenaikan harga pada barang lainnya. Shostak (2002:1) mengatakan inflasi terjadinya lebih disebabkan oleh peningkatan umum di dalam jumlah uang beredar (money supply) bukan karena terjadinya kenaikan harga umum barang dan jasa di pasar. Tamny (2010:1) mencari kejelasan arti sebenarnya inflasi. Dia mengatakan peraih Nobel Milton Friedman telah berjasa menggambarkan inflasi sebagai inflasi selalu dan terjadi di setiap tempat dan merupakan penomena moneter. Tamny juga menyatakan dengan merujuk kepada definisi inflasi Friedman dalam era 1970an dimana inflasi selalu menjadi gejala tumbangnya nilai mata uang pada ketika itu. Tamny juga menyatakan dengan merujuk kepada pernyataan Ben Bernanke bahwa inflasi merupakan fungsi dari terlalu banyaknya pertumbuhan ekonomi di suatu negara.

Badan Pusat Statistik (BPS) mengelompokkan inflasi ke dalam bentuk disagregasi/pengelompokan inflasi. Disagregasi inflasi ini dibagi dua 
kategori pengelompokan yaitu inflasi inti (core inflation) dan inflasi bukan inti (non-core inflation). Inflasi inti dipengaruhi oleh faktor-faktor fundamental antara lain interaksi antara permintaan dan penawaran terhadap barang dan jasa (interaction between demand and supply of goods and services), lingkungan eksternal seperti nilai tukar mata uang, harga komoditi internasional atau inflasi dari mitra dagang, dan ekspektasi inflasi dari pedagang dan konsumen, sedangkan inflasi non-inti dipengaruhi oleh faktor non-fundamental antara lain inflasi makanan yang bergejolak (volatile foods inflation) dimana dominannya dipengaruhi oleh goncangan di dalam bahan makanan tersebut seperti panen yang menurun, gangguan dari kejadian alam baik di dalam negeri maupun luar negeri, inflasi yang disebabkan oleh peraturan pemerintah (administered prices inflation) dimana pada umumnya dipengaruhi oleh goncangan dari pengumuman harga yang dibuat oleh pemerintah seperti harga subsidi BBM, listrik, transportasi umum, dan lain sebagainya.

Pertumbuhan ekonomi suatu negara ditandai dan diukur dengan tingkat Produk Domestik Bruto dan keseluruhan performa ekonomi suatu negara dilihat dari tingkat pertumbuhan ekonomi. BPS mengatakan bahwa PDB pada dasarnya merupakan jumlah nilai tambah yang dihasilkan oleh seluruh unit usaha dalam suatu negara tertentu atau merupakan jumlah nilai barang dan jasa akhir yang dihasilkan oleh seluruh unit ekonomi.

Teori-teori yang menggambarkan hubungan (relationship) antara inflasi dan pertumbuhan ekonomi adalah sebagai berikut:

\section{Teori Pertumbuhan Klasik (Classical Theories)}

Teori Pertumbuhan Klasik ini diperkenalkan oleh Adam Smith yang mengutamakan faktor sisi penawaran (supply side) dimana fungsi produksi sebagai acuannya. Fungsi produksi yang dimaksud adalah: $\mathrm{Y}=f(\mathrm{~L}, \mathrm{~K}, \mathrm{~T})$, dimana: $\mathrm{Y}=$ Pendapatan $\mathrm{L}=$ Buruh $\mathrm{K}=$ Modal $\mathrm{T}=$ Tanah

Y sebagai pendapatan dapat dijelaskan sebagai pertumbuhan ekonomi. L sebagai buruh dapat dijelaskan sebagai penduduk. K sebagai modal dapat dijelaskan sebagai investasi dan T sebagai luas areal tanah. Maka Y sebagai

pendapatan dan dijelaskan sebagai pertumbuhan ekonomi $\left(\mathrm{g}_{\mathrm{y}}\right)$ merupakanfungsi dari pertumbuhan penduduk $\left(\mathrm{g}_{\mathrm{L}}\right)$, pertumbuhan investasi $\left(\mathrm{g}_{\mathrm{K}}\right)$, pertumbuhan areal tanah $\left(\mathrm{g}_{\mathrm{T}}\right)$, dan pertumbuhan 
produktifitas $\left(\mathrm{g}_{\mathrm{f}}\right)$ dimana produktifitas ini berasal dari faktor produksi $\mathrm{L}$,

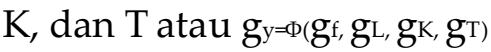

\section{Teori Keynes (Keynesian Theories)}

Teori Keynes menjelaskan hubungan antara inflasi dan pertumbuhan ekonomi dimana keistimewaan teori ini adalah di dalam jangka-pendek (short-run) kurva penawaran agrigat (AS) adalah positif. Kurva AS positif adalah harga naik dan outputjuga naik. Selanjutnya hubungan yang selanjutnya secara hipotesisnya kepada hubungan jangka panjang (long-run relationship) antara inflasi dan pertumbuhan ekonomi dengan dimana inflasi naik akan tetapi pertumbuhan ekonomi turun. Keadaan ini membenarkan pembuktian secara empiris dari beberapa penelitian yang berhubungan dengan hubungan antara inflasi dan pertumbuhan ekonomi bahwa inflasi yang tinggi menyebabkan pertumbuhan ekonomi turun.

\section{Teori Uang dan Moneter (Money and Moneterism theories)}

Teori Uang dan Moneter ini fokus ke dalam komponen sisi penawaran jangka-panjang (long-run supply side properties) dimana Quantity Theory of Money dan Neutrality of Money merupakan dua teori yang mendukung komponen sisi penawaran jangka-panjang ini. Dalam Quantity Theory of Money, Friedmanmenghubungkan inflasi dengan pertumbuhan ekonomi dengan menyamakan jumlah total uang yang dibelanjakan dengan jumlah total uang yang ada (money stock) di dalam ekonomi. Friedman mengusulkan bahwa inflasi yang terjadi diakibatkan oleh uang beredar (money supply) lebih besar efeknya daripada akibat pertumbuhan ekonomi (tingkat produksi). Friedman menyimpulkan bahwa dalam jangka panjang inflasi diakibatkan oleh jumlah pertumbuhan uang dan tidak dipengaruhi oleh pertumbuhan ekonomi. Jika pertumbuhan uang beredar lebih tinggi dari tingkat pertumbuhan ekonomi maka inflasi terjadi.

\section{Teori Neo-Klasikal (Neo-Classical Theories)}

Salah satu model Neo-Klasik dulunya digambarkan oleh Solow (1956) dan Swan (1956). Faktor utama mempengaruhi pertumbuhan jangka-panjang dalam teori ini adalah perubahan teknologi yang menggantikan investasi. Faktor-faktor yang mempengaruhi pertumbuhan jangka-panjang tersebut merupakan faktor eksogen (exogenous factors) termasuk faktor inflasi. Sementara Mundell (1963) salah satu yang pertama menerangkan mekanisme yang berhubungan dengan inflasi dan pertumbuhan ekonomi 
terpisah dari permintaan yang berlebihan (excess demand) terhadap komoditi. Mundell menegaskan bahwa inflasi atau ekspektasi inflasi mengurangi harta seseorang atau inflasi atau ekspektasi inflasi mengurangi bunga uang tersebut (pada saat dibelanjakan). Dengan demikian orang beralih menyimpan uang ke dalam bentuk aset yang mengandung bunga (interest bearing assets). Banyaknya simpanan menambah banyaknya akumulasi kapital dan mempercepat pertumbuhan ekonomi.

5. Teori Pertumbuhan Endogen (Endogenous Growth Theories)

Pertumbuhan ekonomi hanya bergantung kepada satu variabel yaitu keuntungan dari kapital tersebut (rate of return on capital). Karena inflasi ini menurunkan jumlah keuntungan (rateof return), maka mengurangi akumulasi kapital (capital accumulation) dan akibatnya menurunkan pertumbuhan ekonomi. Teori ini mengatakan bahwa pertumbuhan ekonomi akan terus terjadi akibat dari jatuhnya keuntungan kapital tidak melebihi tingkat kritikalnya dan individu akan terus berinvestasi dan menambah kapital akumulasi yang seterusnya menaikkan pertumbuhan ekonomi. Teori Pertumbuhan Endogen ini dikembangkan dengan menegaskan bahwa pertumbuhan ekonomi juga dipengaruhi oleh kapital manusia (human capital) dan kapital fisik (physical capital).

\section{METODE PENELITIAN}

Penelitian ini menggunakan data tahun 1968 hingga tahun 2012. Data IHK berasal dari on-lineInternational Monetary Fund (IMF) menggunakan tahun dasar 2005=100 dan pembentukan inflasi dihitung oleh penulis. Sementara data PDB berasal dari on-lineWorld Bank (WB) dan Bank Indonesia (BI) menggunakan tahun dasar 2000 dan pertumbuhan PDB riil atau pertumbuhan ekonomi dihitung oleh penulis.

Bentuk persamaan dasar pertumbuhan ekonomi terhadap inflasi atau Produk Domestik Bruto adalah fungsi dari Indeks Harga Konsumen adalah sebagai berikut:

$$
\begin{aligned}
& \mathrm{PDB}=f(\mathrm{IHK}) \\
& \mathrm{PDB}_{\mathrm{t}}=\alpha_{0}+\alpha_{1} \mathrm{IHK}_{\mathrm{t}}+\varepsilon_{\mathrm{t}}
\end{aligned}
$$

Pengujian akar unit (unit roots test) dilakukan untuk mengetahui kondisi integrasi dari setiap variabel yang diteliti. Variabel yang digunakan adalah

QE Journal | Vol.03 - No.01 - 45 
variabel inflasi dalam persen dan variabel pertumbuhan ekonomi dalam persen.. Tes/uji akar unit menggunakan Dickey and Fuller Test (DF) dan Augmented DickeyFuller Test (ADF).

Bentuk persamaan umum dari model Augmented DickeyFuller Test (ADF) adalah sebagai berikut:

$$
\Delta \mathrm{y}_{\mathrm{t}}=\alpha_{0}+\alpha_{1} \mathrm{y}_{\mathrm{t}-1}+\sum_{n-1}^{n} \alpha_{1} \Delta \mathrm{y}_{\mathrm{i}}+\delta_{\mathrm{t}}+\mathrm{e}_{\mathrm{t}}
$$

Uji kointegrasi (cointegration test) antara variabel inflasi dan pertumbuhan ekonomi. Ide dasar dari kointegrasi (cointegration) ini adalah jika dua atau lebih variabel seri waktu bergerak hampir dekat bersama-sama dan variabel seri waktu tersebut memiliki tren waktu dan differensiasi konstan (stasioner) maka bisa disebut variabel-variabel seri waktu tersebut memiliki hubungan jangka-panjang (long-run equilibrium relationship).

Jika kointegrasi tidak terdapat di dalam 2 atau 3 variabel yang diuji maka kedua atau ketiga variabel tersebut tidak memiliki hubungan jangkapanjang (no long-run relationship). Dalam menguji kointegrasi di dalam 2 atau 3 variabel maka sering digunakan prosedur tes kemungkinan yang paling tinggi (maximum-likelihood test procedure) oleh Johansen dan Juselius (1990) dan Johansen (1991) di dalam Eviews.

Di dalam prosedur tes kemungkinan yang paling tinggi (maximumlikelihood test procedure) jumlah vektor kointegrasi (cointegration vector) diperoleh dengan melihat signifikasi dari $\Pi$ melalui dua tes kemungkinan (likelihood tests), yaitu: (1) Trace test $(\lambda$ trace $)=-T \sum_{i-r+1}^{n} \ln \left(1-\lambda_{\mathrm{i}}\right)$, dan (2) Maximum eigenvalue $\left(\lambda_{\max }\right)=-T \operatorname{Ln}\left(1-\lambda_{\mathrm{r}+1}\right)$.

Ide pokok dari Granger kausalitas (causality Granger) adalah satu variabel (variabel $\mathrm{x}$ ) bisa mempengaruhi variabel yang lain (variabel y) atau variabel yang lain (variabel y) bisa mempengaruhi variabel yang sebelumnya (variabel $\mathrm{x}$ ) atau variabel $\mathrm{x}$ bisa mempengaruhi variabel $\mathrm{y}$ dan sebaliknya variabel $y$ bisa mempengaruhi variabel $x$.

Bentuk persamaan hubungan antara inflasi dan pertumbuhan ekonomi dalam pembentukan dasar variable IHK dan PDBnya dalam Granger kausalitas adalah sebagai berikut:

$$
\begin{aligned}
& \operatorname{PDB}_{\mathrm{t}}^{*}=\alpha_{0}+\alpha_{1} \mathrm{IHK}_{\mathrm{t}}^{*}+\varepsilon \mathrm{t} \\
& \mathrm{IHK}_{\mathrm{t}}^{*}=\alpha_{2}+\alpha_{3} \mathrm{PDB}^{*}+\mu \mathrm{t}
\end{aligned}
$$




$$
\begin{aligned}
& \Delta \mathrm{PDB}_{\mathrm{t}}^{*}=\alpha_{4}+\alpha_{5} \Delta \mathrm{IHK}_{\mathrm{t}}^{*}+\varepsilon_{\mathrm{t}} \\
& \Delta \mathrm{IHK}_{\mathrm{t}}^{*}=\alpha_{6}+\alpha_{7} \Delta \mathrm{PDB}_{\mathrm{t}}^{*}+\mu_{\mathrm{t}}
\end{aligned}
$$

Model Pembetulan Kesalahan (Error Correction Model) merupakan model yang dibentuk melalui nilai residual (resid)nya. Hasil dari pembentukan Model Pembetulan Kesalahan (ECM) ini melalui nilai koefisien dan probabilitas ( $p$ value) menyatakan secara validitas bahwa terdapat hubungan jangka panjang antara dalam kasus ini inflasi dan pertumbuhan ekonomi.

Pembentukan Model Pembetulan Kesalahan ini dijalankan jika terdapat kointegrasi antara variabel inflasi dan pertumbuhan ekonomi. Kointegrasi menyatakan bahwa terdapat hubungan jangka panjang antara variabel yang dianalisis. Sementara nilai lag dari regresi pembentukan Model Pembetulan Kesalahan menyatakan secara validitas hubungan di dalam jangka pendek.

Bentuk persamaan hubungan antara inflasi dan pertumbuhan ekonomi dimana Error Correction Model dimasukkan adalah sebagai berikut:

$$
\begin{aligned}
& \Delta \mathrm{PDB}_{\mathrm{t}}^{*}=\alpha_{1}+\sum_{j=0}^{S} \alpha_{2 j} \Delta \mathrm{IHK}_{\mathrm{t}-j^{*}}+\sum_{i=1}^{q} \alpha_{3 j} \Delta \mathrm{PDB}_{\mathrm{t}-\mathrm{i}}{ }^{*}-\delta_{1} \mathrm{ECT}_{\mathrm{t}-1}+\mathrm{e}_{\mathrm{t}} \\
& \Delta \mathrm{IHK}_{\mathrm{t}}^{*}=\alpha_{4}+\sum_{j=0}^{s} \alpha_{2 j} \Delta \mathrm{PDB}_{\mathrm{t}-j^{*}}+\sum_{i=1}^{q} \alpha_{3 j} \Delta \mathrm{IHK}_{\mathrm{t}-\mathrm{i}}{ }^{*}-\delta_{2} \mathrm{ECT}_{\mathrm{t}-1}+\mathrm{et}_{\mathrm{t}}
\end{aligned}
$$

Jika tidak terdapat kointegrasi (no cointegration) antara 2 variabel yang dianalisis maka hubungan inflasi dan pertumbuhan tidak bisa diketahui di dalam hubungan jangka panjang tetapi bisa dicari hubungan Granger kausalitasnya. Dalam hubungan Granger kausalitas yang dicari adalah hubungan kausalitas antara PDB dan IHK dan bentuk persamaannya adalah sebagai berikut:

$$
\begin{gathered}
\mathrm{PDB}_{\mathrm{t}}^{*}=\alpha_{1}+\sum_{j=0}^{S} \alpha_{2 j} \mathrm{IHK}_{\mathrm{t}-\mathrm{j}}^{*}+\sum_{i=1}^{q} \alpha_{3 \mathrm{j}} \mathrm{PDB}_{\mathrm{t}-\mathrm{i}}^{*}+\mathrm{e}_{\mathrm{t}} \\
\mathrm{IHK}_{\mathrm{t}}^{*}=\alpha_{4}+\sum_{j=0}^{S} \alpha_{2 j} \mathrm{PDB}_{\mathrm{t}-\mathrm{j}^{*}}+\sum_{i=1}^{q} \alpha_{3 j} \mathrm{IHK}_{\mathrm{t}-{ }^{*}}+\mathrm{e}_{\mathrm{t}}
\end{gathered}
$$

\section{HASIL DAN PEMBAHASAN}

\section{Korelasi antara Inflasi dan Pertumbuhan Ekonomi}

Korelasi antara inflasi dan pertumbuhan ekonomi dimana terdapat korelasi negatif sebesar 4,3\% antara inflasi dan pertumbuhan ekonomi di Indonesia dalam tahun 1968-2012. 


\section{Uji Akar Unit}

Pengujian akar unit pertama terhadap variabel inflasi menggunakan Augmented Dickey Fuller (ADF) dimana diuji dalam kondisi data pertama (at level/original). variabel inflasi tidak memiliki akar unit atau stasioner dalam pengujiannya pada kondisi data original. Ini berarti juga bahwa variabel inflasi bebas dari faktor-faktor yang dapat menjadikan hasil penelitian salah dan bias dan nilai rata-rata, varians serta kovarians variabel inflasi tetap sama. Pengujian akar unit diuji terhadap variabel pertumbuhan ekonomi menggunakan Augmented Dickey Fuller (ADF) dimana diuji dalam kondisi data pertama. Variabel pertumbuhan ekonomi tidak memiliki akar unit atau stasioner dan ini berarti bebas dari faktorfaktor yang dapat menjadikan hasil penelitian salah dan bias dan nilai ratarata, varians serta kovarians variabel pertumbuhan ekonomi tetap sama.

\section{Uji Kointegrasi}

Berdasarkan uji trace dengan hipotesis nol adalah tidak ada jumlah persamaan kointegrasi didapat nilai probabilitasnya 0,002\% lebih kecil dari nilai kritikalnya 5\%. Ini berarti bahwa hipotesis nol ditolak sebaliknya hipotesis alternatif diterima maka terdapat satu persamaan kointegrasi antara variabel inflasi dan pertumbuhan ekonomi. Seterusnya diuji dengan hipotesis nol yang menyatakan terdapat paling banyak satu persamaan kointegrasi dan didapat nilai probabilitasnya 0,02\% lebih kecil dari nilai kritikalnya 5\%. Ini berarti bahwa hipotesis nol ditolak sebaliknya hipotesis

alternatif diterima maka terdapat dua persamaan kointegrasi antara variabel inflasi dan pertumbuhan ekonomi. Dengan demikian melalui uji trace dinyatakan secara validitas terdapat hubungan kointegrasi antara inflasi dan pertumbuhan ekonomi dan selanjutnya dinyatakan bahwa antara inflasi dan pertumbuhan ekonomi memiliki hubungan di dalam jangka panjang. Berdasarkan uji Max-Eigen dengan hipotesis nol adalah tidak ada jumlah persamaan kointegrasi didapat nilai probabilitasnya 0,0632\% lebih kecil dari nilai kritikalnya 5\%. Ini berarti bahwa hipotesis nol ditolak sebaliknya hipotesis alternatif diterima maka terdapat satu persamaan kointegrasi antara variabel inflasi dan pertumbuhan ekonomi. Seterusnya diuji dengan hipotesis nol yang menyatakan terdapat paling banyak satu persamaan kointegrasi dan didapat nilai probabilitasnya $0,02 \%$ lebih kecil dari nilai kritikalnya 5\%. Ini berarti bahwa hipotesis nol ditolak sebaliknya hipotesis alternatif diterima maka terdapat dua persamaan

QE Journal | Vol.03 - No.01 - 48 
kointegrasi antara variabel inflasi dan pertumbuhan ekonomi.Dengan demikian melalui uji Max-eigen dinyatakan secara validitas terdapat hubungan kointegrasi antara inflasi dan pertumbuhan ekonomi dan selanjutnya dinyatakan bahwa antara inflasi dan pertumbuhan ekonomi memiliki hubungan di dalam jangka panjang. Oleh karena itu melalui tes kointegrasi antara inflasi dan pertumbuhan ekonomi dinyatakan secara validitas bahwa terdapat hubungan kointegrasi dimana memiliki hubungan jangka panjang antara inflasi dan pertumbuhan ekonomi.

\section{Model Pembetulan Kesalahan (Error Correction Model)}

Pertama dibentuk inflasi sebagai variabel dependent dan didapat nilai probabilitas untuk $\mathrm{U}(-1)$ sebagai validitasnya hubungan jangka panjang adalah signifikan dimana nilainya 0,00\% lebih kecil dari nilai kritikalnya $5 \%$ dan juga koefisien $\mathrm{U}(-1)$ adalah negatif maka secara validitas pertumbuhan ekonomi mempunyai hubungan jangka panjang terhadap inflasi. Nilai koefisien $U(-1)=-0,89$ berarti sebesar 89 persen pertumbuhan ekonomi mengkoreksi/membetulkan terhadap inflasi menuju titik ekuilibrium (equilibrium point)nya. Sementara untuk hubungan jangka pendek dilihat dari nilai probabilitas $\mathrm{D}$ (perekon) adalah sebesar 0,009\% adalah lebih kecil dari nilai kritikalnya 5\%. Ini berarti bahwa secara signifikan pertumbuhan ekonomi mempunyai hubungan jangka pendek terhadap inflasi. Nilai koefisien $\mathrm{D}$ (perekon) $=-1,17$ berarti kenaikan sebesar 1 persen inflasi, pertumbuhan ekonomi turun 117 persen. Selanjutnya variabel pertumbuhan ekonomi dibentuk sebagai variabel dependent. Nilai probabilitas untuk $\mathrm{U}(-1)$ sebagai validitasnya hubungan jangka panjang adalah signifikan dimana nilainya 0,039\% lebih kecil dari nilai kritikalnya $5 \%$ dan juga koefisien $U(-1)$ adalah negatif maka secara validitas inflasi mempunyai hubungan jangka panjang terhadap pertumbuhan ekonomi. Nilai koefisien $U(-1)=-0,18$ berarti sebesar 18 persen inflasi mengkoreksi/membetulkan terhadap pertumbuhan ekonomi menuju titik ekuilibriumnya. Sementara untuk hubungan jangka pendek dilihat dari nilai probabilitas $\mathrm{D}$ (inflasi) adalah sebesar 0,009\% adalah lebih kecil dari nilai kritikalnya 5\%. Ini berarti bahwa secara signifikan pertumbuhan ekonomi mempunyai hubungan jangka pendek terhadap inflasi. Nilai koefisien $\mathrm{D}$ (inflasi) $=-0,20$ berarti kenaikan sebesar 1 persen pertumbuhan ekonomi, inflasi turun 20 persen.

QE Journal | Vol.03 - No.01 - 49 


\section{Uji Kausalitas Granger}

Dari hipotesis nol IHK tidak mempengaruhi PDB. Nilai probabilitasnya adalah 9,9\%. 9,9\% lebih besar dari nilai kritikalnya 5\%. Ini berarti bahwa Hipotesis nol diterima sebaliknya hipotesis alternative ditolak maka dapat dijelaskan bahwa Indeks Harga Konsumen tidak mempunyai pengaruh terhadap Produk Domestik Bruto. Ini berarti juga terjadinya kenaikan harga barang dan jasa di pasar tidak mempengaruhi tingkat pendapatan masyarakat di Indonesia dalam periode waktu 1968-2012. Selanjutnya dari hipotesis nol PDB tidak mempengaruhi IHK dimana nilai probabilitasnya adalah 2,7\% lebih kecil dari nilai kritikalnya 5\%. Ini berarti bahwa Hipotesis nol ditolak sebaliknya hipotesis alternative diterima maka dapat dijelaskan bahwa Produk Domestik Bruto mempunyai pengaruh terhadap Indeks Harga Konsumen. Ini berarti juga terjadinya peningkatan pendapatan masyarakat dapat mempengaruhi peningkatan harga barang dan jasa di pasar di Indonesia dalam periode 1968-2012.

\section{SIMPULAN DAN SARAN}

\section{Simpulan}

Korelasi antara inflasi dan pertumbuhan ekonomi di Indonesia dalam tahun 1968-2012 adalah berkorelasi negatif sebesar 4,3\%. Hubungan kausalitas satu arah terjadi Produk Domestik Bruto mempengaruhi Indeks Harga Konsumen sebaliknya hubungan kausalitas satu arah tidak terjadi terhadap Indeks Harga Konsumen mempengaruhi Produk Domestik Bruto di Indonesia dalam tahun 1968-2012. Hubungan jangka pendek dan jangka panjang antara inflasi dan pertumbuhan ekonomi di Indonesia dalam tahun 1968-2012 terdapat secara signifikan.

\section{Saran}

Pemerintah sebaiknya harus menghindari tingkat inflasi yang terlalu tinggi agar harga barang dan jasa atau inflasi yang bisa dikendalikan dapat memberikan pengaruh positif terhadap pertumbuhan ekonomi. Pertumbuhan ekonomi juga harus dikendalikan agar pertumbuhan ini tidak menyebabkan inflasi. Sebaiknya pemerintah harus mengendalikan harga Bahan Bakar Minyak di pasar domestik walaupun terjadi gejolak kenaikan harga minyak mentah di pasar internasional. Sektor keuangan

QE Journal | Vol.03 - No.01 - 50 
harus tetap ditingkatkan dan dipertahankan dan terus dikontrol oleh Bank Indonesia Pemerintah sebagai pengambil kebijakan fiskal harus berhatihati dalam mengelola Anggaran Pendapatan dan Belanja Negara dimana

sektor-sektor yang rentan menimbulkan gejola/kenaikan harga terhadap barang dan jasa di pasar harus benar-benar diperhatikan pemerintah.

\section{DAFTAR PUSTAKA}

Ahmed, Shamim dan Mortaza, Golam, M. 2005. Inflation and Economic Growth in Bangladesh: 1981-2005. Working Paper Series, retrieved from www.esocialsciences.org on January 52014.

Ahluwalia, Singh, M. 2011. Growth vs Inflation: Government's Balancing Act, retrieved from http://www.youtube.com on January 62014.

Bank Indonesia. 2004. Laporan Perekonomian Indonesia Tahun 1998/1999.

Baily, Neil. M. dan Friedman, Philip. 1995. Macroeconomics, Financial Markets, and the International Sector (2 ${ }^{\text {nd }}$ Edition). New York: Irwin.

Chimobi, Philip, O. 2010. Inflation and Economic Growth in Nigeria. Journal of Sustainable Development, retrieved from www.ccsenet.org on Januar 62014.

Erbaykal, Erman dan Okuyan, Aydan H. 2008. Does Inflation Depress Economic Growth? Evidence from Turkey. International Research Journal of Finance and Economics, retrieved fromhttp://www.eurojournal.com January 62014.

Firdausy, Mulya, C. 2005. Productivity Performance in Developing Countries, Country Case Studies: Indonesia, retrieved from http://www.unido.org on January6 2014.

Gokal, Vikesh dan Hanif, Subrina. 2004. Relationship between Inflation and Economic Growth. Working Paper 2004/04, retrieved from http://www.reservebank.gov on January 52014.

Gujarati, D. 2003. Basic Econometrics (4 ${ }^{\text {th }}$ Edition). New York: Prentice-Hall International Editions

Hossain, Akhtar. 2005. The Granger-Causality between Money Growth, Inflation, Currency Devaluation, and Economic Growth in Indonesia:

QE Journal | Vol.03 - No.01 - 51 
1954-2002. International Journal of Applied Econometrics and Quantitatives Studies, retrieved from http://www.usc.es on January 6 2014.

Inggrid. 2006. Sektor Keuangan dan Pertumbuhan ekonomi di Indonesia: Pendekatan Kausalitas dalam Multivariate Vector Error Correction Model (VECM). Jurnal Manajemen dan Kewirausahaan. Retrieved from http://puslit2.petra.ac.id/ejournal/index.php/man/article on 6 January 62014.

Investopedia. 2013. Inflation: Definition of Inflation, retrieved from http://www.investopedia.com on December 202013.

Krugman, Paul. 2011. Definition of Inflation. Economic Policy Journal,retrieved from http://www.economicpolicyjournal.com on December 202013.

Mundell, Robert. 1963. Inflation and Real Inflation. Journal of Political Economy.

Mubarik, Ali, Y. 2005. Inflation and Growth: An Estimate of the Threshold Level of Inflation in Pakistan. SBP-Research Bulletin, retrieved from http://www.sbp.org.pk/research/bulletin on January 62014.

Mallik, Girijasankar and Chowdhury, Anis. 2001. Inflation and Economic Growth: Evidence from Four South Asian Countries. Asian-Pacific Development Journal, retrieved from http://e.unescap.org/ drpad/publication/journal 8 1// on January 62014.

Shostak, Frank. Rabu. 2002. Defining Inflation, retrieved from http://mises.org/daily/908 on December 202013.

Todaro, Michel, P. 1992. Economic Development in the Third World (4 $4^{\text {th }}$ Edition). Singapore: Longman

Tamny, John. 2010. The True Meaning of Inflation, retrieved from http://www.forbes.com/2010/01/24/inflation-prices-gold-standardopinions-columnists-john-tamny.html on December 202013.

The Economic Times. 2013. Definition of Inflation, retrieved from http://economictimes.indiatimes.com/definition/Inflation, on December 202013. 